\title{
The azygos lobe and vein: interesting and typical clinical image
}

\author{
Premnath Reddy Karre, ${ }^{1}$ Gary Brooks Cooper $\|^{2}$ \\ ${ }^{1}$ Department of Hospital Medicine, Christus Saint Michael Health System, Texarkana, Texas, United States; \\ 2Department of Imaging and Survey, Cooper Services, Texarkana, Texas, United States
}

Correspondence to Dr Premnath Reddy Karre, karreprn@gmail.com

\section{DESCRIPTION}

A 38-year-old male admitted to the hospital with chest pain for few days. He does not have any significant medical and surgical problems. Physical examination, lab work, imaging studies and exercise cardiolite stress were normal. Eventually, we concluded that this chest pain was most likely secondary to musculoskeletal origin. We found azygos lob incidentally on chest x-ray and computed axial tomography of chest. These images have typical appearance of azygos lobe, fissure and vein. The azygos lobe (azygos lobe in figures 1 and 2) is a uncommon anomaly that is found in $1 \%$ of anatomic specimens, ${ }^{1}$ on about $0.4 \%$ of chest radiographs ${ }^{2}$ and $1.2 \%$ of high resolution CT. ${ }^{3}$ The azygos lobe is a developmental anomaly but not a true accessory lobe. On chest radiographs, azygos fissure

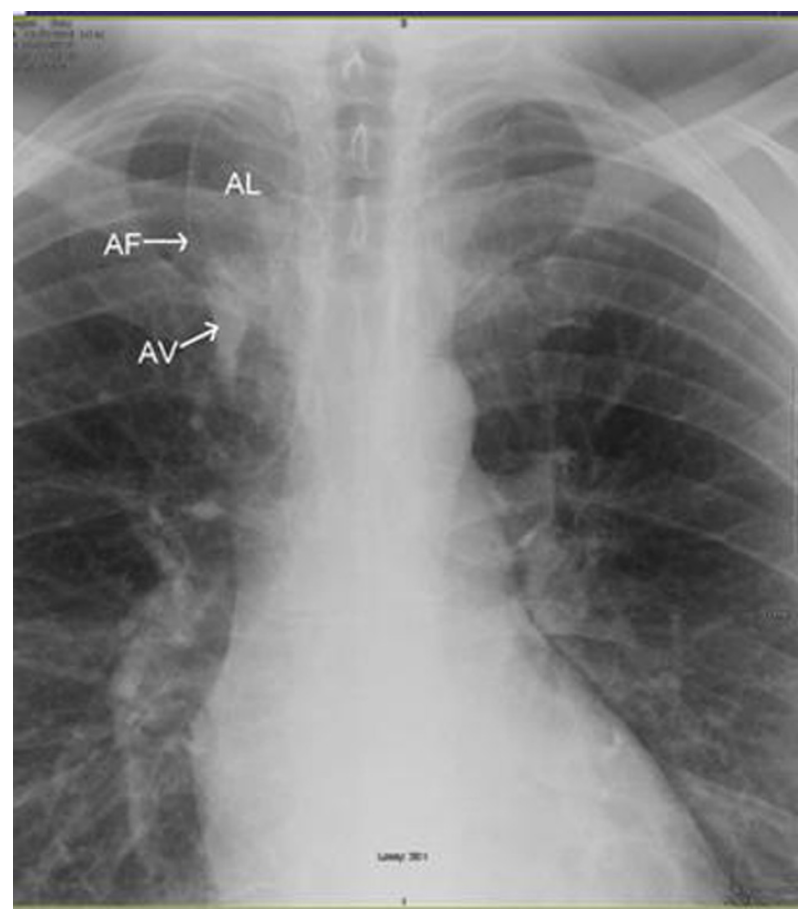

Figure 1 Chest x-ray image. (azygos fissure in figure 1) is visible as a fine convex line and its upper portion has triangular shape due to extrapleural areolar tissue and lower portion has tear-shaped shadow due to azygos vein (azygos vein in figure 1). Anatomy of azygos lobe is clinically important during thoracic surgical procedures. Cases of spontaneous pneumothorax have reported in patients with azygos lobe.

Acknowledgements The authors would like to thank Dr Martin Joshua G MD for his contribution.

\section{Competing interests None.}

Patient consent Obtained.

\section{REFERENCES}

1. Boyden EA. The distribution of bronchi in gross anomalies of the right upper lobe particularly lobes subdivided by the azygos vein and those containing pre-eparterial bronchi. Radiology 1952;58:797-807.

2. Mata J, Cáceres J, Alegret X, et al. Imaging of the azygos lobe: normal anatomy and variations. AJR Am J Roentgenol 1991;156:931-7.

3. Aziz A, Ashizawa K, Nagaoki K, et al. High resolution CT anatomy of the pulmonary fissures. J Thorac Imaging 2004;19:186-91.

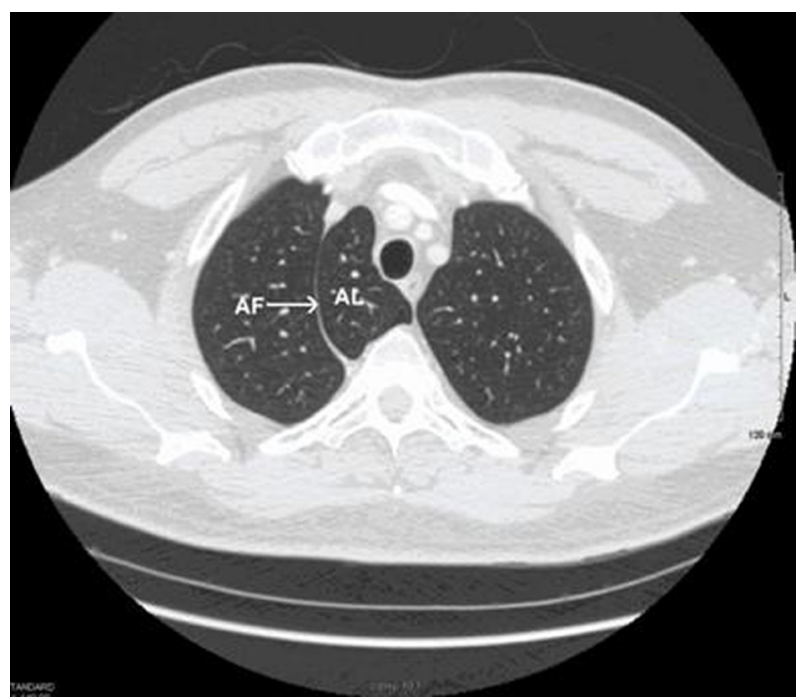

Figure 2 Computed axial tomography image. AL, azygos lobe; $A F$, azygos fissure; $A V$, azygos vein. 


\section{BMJ Case Reports}

This pdf has been created automatically from the final edited text and images.

Copyright 2011 BMJ Publishing Group. All rights reserved. For permission to reuse any of this content visit http://group.bmj.com/group/rights-licensing/permissions.

BMJ Case Report Fellows may re-use this article for personal use and teaching without any further permission.

Please cite this article as follows (you will need to access the article online to obtain the date of publication).

Karre PR, Gary Brooks C, Gary Brooks C. The azygos lobe and vein: interesting and typical clinical image. BMJ Case Reports 2011;

10.1136/bcr.05.2011.4266, date of publication

Become a Fellow of BMJ Case Reports today and you can:

- Submit as many cases as you like

- Enjoy fast sympathetic peer review and rapid publication of accepted articles

- Access all the published articles

- Re-use any of the published material for personal use and teaching without further permission

For information on Institutional Fellowships contact consortiasales@bmjgroup.com

Visit casereports.bmj.com for more articles like this and to become a Fellow 